\title{
Analisis Hukum Dampak Kenaikan Upah Minimum Terhadap Eksistensi Perusahaan Di Kabupaten Karawang
}

\author{
M. Gary Gagarin Akbar, Dan Deny Guntara \\ Universitas Buana Perjuangan Karawang \\ Email : gary.akbar@ubpkarawang.ac.id, guntaradeny@gmail.com
}

\begin{abstract}
Wages from the workers side are a right that is seen from the amount, while from the business side, it is associated with productivity. Wage problems are always a concern of all circles, both from government, employers, trade unions, and the general public. The increase in minimum wages must be considered in such a way as not to have a negative impact on the company, as well as workers / laborers and the community. The question then is, what are the legal consequences for employers who are unable to implement minimum wages for workers /laborers, and how the impact of rising minimum wages on the existence of a company. This research method uses qualitative methods with an empirical juridical approach method. The results of this study are that entrepreneurs who are unable to apply a wage can submit a wage suspension, and if they do not propose a wage suspension, the employer can be subject to criminal penalties. The increase in minimum wages can result in the closure of existing companies, especially textile companies, in contrast to foreign companies, because the minimum wage is the lowest standard of wages in the company, while for workers / labor the wage increase does not have an impact on increasing welfare, because the price of basic necessities also increases.
\end{abstract}

Keyword : Minimum Wage, Workers / Labor, Company Existence.

\begin{abstract}
Abstrak
Upah dari sisi pekerja, merupakan suatu hak yang dilihat dari jumlah, sedangkan dari sisi pemgusaha, dikaitkan dengan produktivitas. Permasalahan upah selalu menjadi perhatian semua kalangan, baik dari pemerintah, pengusaha, serikat pekerja/buruh, dan masyarakat umum. Kenaikan upah minimum harus diperhatikan sedemikian rupa agar tidak menimbulkan dampak negatif bagi perusahaan, maupun pekerja/buruh dan masyarakat. Pertanyaannya kemudian adalah, apa akibat hukum bagi pengusaha yang tidak mampu menerapkan upah minimum bagi pekerja/buruh, dan bagaimana dampak kenaikan upah minimum terhadap eksistensi suatu perusahaan. Metode penelitian ini menggunakan metode kualitatif dengan metode pendekatan yuridis empiris. Hasil penelitian ini yaitu pengusaha yang tidak mampu menerapkan upah minum dapat mengajukan penangguhan upah, dan bila tidak mengajukan penangguhan upah maka pengusaha dapat dikenakan pidana. Kenaikan
\end{abstract}


upah minimum bisa berakibat tutupnya perusahaan yang ada, terutama perusahaan tekstil, berbeda halnya dengan perusahaan asing, karena upah minimum adalah standar upah terendah di perusahaan tersebut, sedangkan bagi pekerja/buruh kenaikan upah tidak berdampak terhadap peningkatan kesejahteraan, karena harga kebutuhan pokokpun ikut naik.

Kata Kunci : Upah Minimum, Pekerja/Buruh Eksistensi Perusahaan.

Istinbath: Jurnal Hukum

Website : http://e-journal.metrouniv.ac.id/index.php/istinbath/index

Received : 2019-04-16| Reviewed : 2019-05-26| Published : 2019-06-12.

(c) (i) (2)

This is an open access article distributed under the terms of the Creative Commons Attribution 4.0 International License, which permits unrestricted use, distribution, and reproduction in any medium, provided the original work is properly cited.

\section{Pendahuluan}

Hubungan antara pihak pekerja/buruh dengan pengusaha dalam perspektif hukum ketenagakerjaan disebut hubungan industrial. Pengertian hubungan industrial berdasarkan ketentuan Pasal 1 angka 16 Undang-Undang Nomor 13 Tahun 2003 adalah suatu sistem hubungan yang terbentuk antara para pelaku dalam proses produksi barang dan/atau jasa yang terdiri atas unsur pengusaha, pekerja/buruh, dan pemerintah yang didasarkan pada nilai Pancasila dan Undang-Undang Dasar Negara Republik Indonesia Tahun 1945. Berdasarkan pengertian tersebut dapat diuraikan unsur-unsur dari hubungan industrial, yakni adanya suatu sistem hubungan industrial, adanya pelaku yang meliputi pengusaha, pekerja/buruh dan pemerintah, adanya proses produksi barang dan/atau jasa. ${ }^{1}$

Di dalam hukum ketenagakerjaan, pengupahan merupakan masalah yang sangat penting dan krusial. Di satu sisi, upah adalah hak yang dimilik oleh pekerja sebagai suatu imbalan atas jasa dan/atau tenaga yang telah diberikan, tetapi di sisi yang lain, upah merupakan biaya bagi pengusaha. Menurut UU No.13 Tahun 2003 tentang Ketenagakerjaan, Pasal 1 butir 30 menyatakan bahwa upah adalah hak pekerja/buruh yang diterima atau dinyatakan dalam bentuk uang sebagai imbalan dari pengusaha atau

\footnotetext{
${ }^{1}$ Asri Wijayanti, Hukum Ketenagakerjaan Pasca Reformasi (Jakarta: Sinar Grafika, 2009).
} 
pemberi kerja kepada pekerja/buruh yang ditetapkan dan dibayarkan menurut suatu perjanjian kerja, kesepakatan, atau peraturan perundang-undangan, termasuk tunjangan bagi pekerja/buruh dan keluarganya atas pekerjaan dan/atau jasa yang telah atau akan dilakukan. $^{2}$

Dalam rangka perlindungan terhadap buruh, pemerintah mewujudkannya dalam bentuk adanya standar upah minimum atau yang biasa disebut dengan upah minimum. Pada Pasal 88 ayat (3) huruf a menyatakan bahwa "kebijakan pengupahan yang melindungi pekerja/buruh sebagaimana dimaksud ayat (2) meliputi upah minimum". 3

Pada tahun 2015 yang lalu pemerintah mengeluarkan Peraturan Pemerintah (PP) No.78 Tahun 2015 tentang Pengupahan. Di dalam PP ini menentukan bahwa kenaikan upah terhadap pekerja didasarkan pada inflasi dan pertumbuhan ekonomi nasional. Kemunculan PP ini memang mendapatkan banyak sorotan dari berbagai pihak terutama kaum buruh karena dianggap bertentangan dengan peraturan UU No.13 Tahun 2003 tentang Ketenagakerjaan. Pada tahun 2017, Kabupaten Karawang menjadi daerah dengan Upah Minimum Kabupaten (UMK) tertinggi se-indonesia sebesar Rp. 3.605.272,- (tiga juta enam ratus lima ribu dua ratus tujuh puluh dua rupiah). Ini mengalami kenaikan 8,25 persen dari tahun sebelumnya.

Kebijakan Upah Minimum ini memang terkadang terkesan diabaikan oleh para pengusaha, yang diindikasikan dengan banyaknya pengusaha belum melaksanakan kebijakan tersebut di perusahaannya. Hal ini seringkali memicu berbagai macam persepsi dan reaksi, baik yang posisitif maupun negatif, hampir dari seluruh lapisan masyarakat dari berbagai daerah di Indonesia. Persepsi negatif dalam artian bagaimana seseorang memandang atau mengartikan atau memahami sesuatu secara tidak baik, biasanya muncul dari pekerja yang upahnya jauh di bawah upah minimum yang telah ditetapkan. ${ }^{4}$

\footnotetext{
${ }^{2}$ Diana Fajarwati, “Evaluasi Pelaksanaan Kebijakan Perumusan Upah Minimum Kota Bekasi Tahun 2010," t.t., 14.

3 “Undang-Undang Nomor 13 Tahun 2003 tentang Ketenagakerjaan," 2003.

${ }^{4}$ Gabriella Ayu Fajar T.W., Hermawan, dan Ainul Hayat, "Persepsi Pekerja Terhadap Implementasi Kebijakan Upah Minimum Kota (Umk) (Studi Di Kecamatan Sukun Kota Malang)," Jurnal Administrasi Publik (JAP) 1, no. 3 (t.t.): 125-34.
} 
Sebagai akibatnya, buruh sering melakukan demonstrasi berkenaan dengan upah minimum ini, Mengenai aksi yang dilakukan para buruh tersebut, tentu berkaitan dengan adanya segitiga kepentingan antara kekuatan yang memiliki masing-masing interest, yaitu kekuatan buruh, pengusaha, dan pemerintah. Negara, yang kemudian direpresentasikan dan/atau diwakili oleh pemerintahan daerah, secara rutin mengeluarkan kebijakan Upah Minimum bagi buruh yang bekerja pada perusahaanperusahaan di wilayahnya sebagai standar kecukupan bagi kehidupan buruh. Akan tetapi, tidak jarang pengusaha menganggap kebijakan tersebut tidak sesuai melakukan gugatan terhadap kebijakan tersebut ke pengadilan. ${ }^{5}$

Beberapa waktu yang lalu, pemerintah Provinsi Jawa Barat resmi menetapkan UMK tahun 2018 di 27 kota/kabupaten. Kabupaten Karawang kembali menjadi daerah yang memiliki UMK paling tinggi sebesar Rp. 3.919.291,13 dan terendah Kabupaten Pangandaran sebesar Rp. 1.558.793,94. Di bawah ini adalah 5 (lima) kota/kabupaten yang memiliki UMK tertinggi untuk tahun 2018 di Jawa Barat dapat kita lihat pada tabel berikut. ${ }^{6}$

Tabel 1.1

\begin{tabular}{|l|l|l|}
\hline No & \multicolumn{1}{|c|}{ Kota/Kabupaten } & \multicolumn{1}{c|}{ UMK } \\
\hline 1 & Kabupaten Karawang & Rp. 3.919.291,19 \\
\hline 2 & Kota Bekasi & Rp. 3.915.353,71 \\
\hline 3 & Kabupaten Bekasi & Rp. 3.837.939,63 \\
\hline 4 & Kota Depok & Rp. 3.584.700,29 \\
\hline 5 & Kota Bogor & Rp. 3.557.146,66 \\
\hline
\end{tabular}

\footnotetext{
${ }^{5}$ Muhammad Iqbal Damanik, “Upah Minimum Dalam Politik Media Massa (Studi Analisis Wacana Kritis Keberpihakan Harian Koran Tempo dan Harian Kompas dalam Pemberitaan Polemik Penentuan Upah Minimum Kawasan Industri Bekasi - Jawa Barat)," Jurnal Ilmu Komunikasi Flow 1, no. 3 (2013): 1-15.

${ }^{6}$ Mukhlis Dinillah Solehudin Mochamad, "UMK Karawang Tertinggi dan Pangandaran Terendah di Jawa Barat," detiknews, diakses 11 Juni 2019, https://news.detik.com/berita-jawa-barat/d-3737173/umkkarawang-tertinggi-dan-pangandaran-terendah-di-jawa-barat.
} 
Penetapan UMK tersebut tertuang dalam Keputusan Gubernur Jawa Barat Nomor 561/Kep.1065-Yanbangsos/2017 tentang Upah Minimum Kabupaten/Kota di daerah Provinsi Jawa Barat. Kenaikan UMK tersebut disesuaikan dengan penghitungan yang telah ditetapkan oleh pemerintah yaitu 8,21 persen. Kenaikan tersebut didasarkan pada angka inflasi dan pertumbuhan ekonomi nasional.

Kenaikan upah minimum di Kabupaten Karawang tersebut ibarat 2 (dua) sisi mata uang. Di satu sisi kenaikan tersebut patut kita apresiasi karena pastinya akan meningkatkan kesejahteraan bagi pekerja/buruh. Tetapi di sisi yang lain kenaikan upah minimum ini akan menjadi beban bagi suatu perusahaan. Berdasarkan uraian tersebut di atas, maka penulis tertarik untuk melakukan analisis hukum dampak kenaikan upah minimum terhadap eksistensi perusahaan di kabupaten karawang. Dengan fokus permasalahan Apa akibat hukum bagi perusahaan yang tidak menerapkan upah minimum ?, Dan bagaimanakah eksistensi suatu perusahaan terhadap kenaikan upah minimum di Kabupaten Karawang ?.

\section{Metode Penelitian}

Penelitian ini menggunakan metode pendekatan yuridis empiris yaitu untuk mengevaluasi keterkaitan aspek-aspek empiris. Metode penelitian yang dilakukan dalam program ini diawali dengan pengumpulan data awal metode deskriptif. Informasi awal yang sudah didapatkan selanjutnya akan dicari akar permasalahannya lalu dijabarkan dalam bentuk teori dengan mendapatkan dukungan bahan dari informasi kepustakaan terkait yang bersifat relevan. Program penelitian ini akan melakukan penelitian langsung terhadap lembaga atau obyek penelitiannya (penelitian lapangan). Sumber data merupakan asal dari mana data penelitian dapat diperoleh. Sumber data yang dipergunakan dalam penelitian ini meliputi:

1. Data Primer, merupakan data pokok yang diperlukan dalam penelitian yang berasal dari responden dan informan dan merupakan sumber data utama yang diperoleh peneliti dari responden yaitu pengusaha, pekerja/buruh, serikat pekerja/buruh, dan masyarakat di Kabupaten Karawang, dan Informan/orang yang dimanfaatkan untuk memberikan tentang situasi dan kondisi latar penelitian yang terdiri dari Pengusaha dan serikat pekerja/buruh. 
2. Data Sekunder, merupakan data yang menunjang data primer dan merupakan pelengkap bagi data primer. Data sekunder ini merupakan data dari penelitian kepustakaan, yang terdiri dari 3 (tiga) bahan hukum yakni: Bahan hukum primer, bahan hukum yang sifatnya mengikat berupa peraturan perundang- undangan yang berlaku dan ada kaitannya dengan permasalahan yang dibahas, antara lain Kitab Undang-Undang Hukum Perdata (KUH Perdata); Undang-Undang Nomor 13 Tahun 2003 tentang Ketenagakerjaan dan Peraturan Pemerintah Nomor 78 Tahun 2015 tentang Pengupahan; Bahan hukum sekunder, bahan hukum yang sifatnya menjelaskan bahan hukum primer, dimana bahan hukum sekunder berupa literaur, hasil karya penelitian (jurnal, karya ilmiah); Bahan hukum tersier adalah bahan hukum sebagai pelengkap dari kedua bahan hukum sebelumnya yang berupa kamus hukum dan kamus bahasa Indonesia.

Teknik pengumpulan data dimaksudkan sebagai cara untuk memperoleh data dalam penelitian. Teknik pengumpulan data yang digunakan dalam penelitian ini antara lain melakukan wawancara; melakukan observasi; dan mengumpulkan dokumendokumen serta melakukan studi pustaka yang berkaitan dengan permasalahan yang dicari dalam penelitian ini.

Analisis data penelitian menggunakan data kualitatif model interaktif yang berlangsung terus menerus dan berkelanjutan. Analisis model interaktif melalui berbagai alur kegiatan melalui langkah-langkah sebagai berikut:

1. Pengumpulan Data, mencari dan mengumpulkan data yang diperlukan yang dilakukan terhadap berbagai jenis dan bentuk apa yang ada di lapangan kemudian data tersebut dicatat. Pengumpulan data ini dilakukan berkaitan dengan data penelitian yang ada di lapangan yaitu peneliti melakukan wawancara kepada pengusaha, HRD Perusahaan, pekerja/buruh maupun pihak serikat pekerja/buruh.

2. Penyajian Data, sekumpulan informasi tersusun yang memberi kemungkinan adanya penarikan kesimpulan dan pengambilan tindakan. Data yang diperoleh dari obyek penelitian dari data primer maupun sekunder akan disusun secara sistematis dan disajikan dalam bentuk laporan penelitian secara kualitatif yaitu berdasarkan konsep teori, peraturan perundang-undangan tentang ketenagakerjaan dan aturan tentang pengupahan. 
3. Menarik Kesimpulan, tinjauan ulang pada catatan lapangan atau kesimpulan dapat ditinjau sebagaimana yang muncul dari data yang harus diuji kebenarannya, kekokohan dan kecocokannya yaitu mencapai validitasnya. Pengumpulan data, reduksi data, penyajian data dan menarik simpulan sebagai suatu yang berkaitan pada saat sebelum, selama dan sesudah pengumpulan data berlangsung. Dalam hal ini peneliti mengoreksi kembali hasil penelitian dengan catatan yang terdapat di lapangan selama penelitian. Setelah data tersebut sesuai, maka dapat ditarik kesimpulan dari setiap item yang ada. tahapan analisis data kualitatif diatas melibatkan beberapa komponen data interaksi yang merupakan suatu proses siklus dalam melakukan analisis data.

\section{Pembahasan}

\section{Upah Minimum}

Menurut UU No.13 Tahun 2003 tentang Ketenagakerjaan, Pasal 1 butir 30 menyatakan bahwa upah adalah hak pekerja/buruh yang diterima atau dinyatakan dalam bentuk uang sebagai imbalan dari pengusaha atau pemberi kerja kepada pekerja/buruh yang ditetapkan dan dibayarkan menurut suatu perjanjian kerja, kesepakatan, atau peraturan perundang-undangan, termasuk tunjangan bagi pekerja/buruh dan keluarganya atas pekerjaan dan/atau jasa yang telah atau akan dilakukan.

Setiap Negara mempunyai pasti memiliki aturan dan ketentuan masing-masing yang di buat dan diterapkan oleh pemerintah, sebagai pilar utama, berkenaan dengan upah yang diberikan kepada mereka yang menjadi pekerja dan pengusaha, agar hubungan antara buruh dan pengusaha dapat seiring sejalan antara hak dan kewajiban secara adil. Selain itu pemerintah harus berperan serta berfungsi sebagai bagian dari struktur penegakan hukum, dan penengah bila terjadi konflik atau perselisihan kepentingan yang terjadi antara buruh dan/atau pekerja secara adil. Karena pemerintah selain memperhatikan kesejahteraan buruh, juga harus mampu menjaga kelangsungan proses produksi demi kepentingan yang lebih luas. ${ }^{7}$

Berkenaan dengan tenaga kerja, Sampai saat ini situasi kompetisi antar tenaga kerja/buruh di Indonesia demikian ketat, meskipun belum berada dalam nuansa

\footnotetext{
${ }^{7}$ Firman Widia Nanda, "Peran Pemerintah Daerah Dalam Pelaksanaan Upah Minimum Regional Bagi Usaha Kecil Dan Menengah (Studi Di Dinas Sosial Dan Tenaga Kerja Kota Kediri)," t.t., 17.
} 
kompetisi sempurna (perfect competition), maka analisis mengenai dampak dari kebijakan penetapan upah minimum juga akan bergantung pada situasi persaingan tenaga kerja tersebut. Apalagi kecenderungan persaingan tenaga kerja/buruh di Indonesia umumnya masih bersifat monopsonistik dalam kompetisinya, dan kompetisi yang bersifat monopsonistik ini hanya terjadi pada perusahaan besar yang berada di daerah terpencil. Dampaknya adalah, kompetisi ini hanya menguntungkan bagi para pekerja dengan produktivitas yang tinggi, atau diatas rata-rata, atau the best workers, serta hanya berlaku pada lapangan-lapangan kerja tertentu juga. ${ }^{8}$

Karena dalam dunia kerja, pemberian upah pada umumnya selalu mempertimbangkan kemampuan pekerja yang tercermin dalam produktivitas kerja. Pemerintah melakukan intervensi karena sangat berkepentingan untuk menyelaraskan antara upah yang memenuhi penghidupan yang layak bagi kemanusiaan dan pencapaian produktivitas kerja, yaitu dengan memperhatikan: ${ }^{9}$

1. Kebutuhan hidup pekerja;

2. Kesenjangan sosial;

3. Prestasi kerja, dan

4. Nilai kemanusiaan dan harga diri.

Pemerintah memberlakukan kebijakan Penetapan Upah Minimum yang tadinya dilandasi oleh Kebutuhan Fisik Minimum (KFM) berkembang menjadi Kebutuhan Hidup Minimum (KHM), berlaku secara mikro-regional dengan maksud: ${ }^{10}$

1. Sebagai jaring pengaman;

2. Sebagai sarana untuk meningkatkan taraf hidup kelompok terendah;

3. Sebagai alat terjadinya pemerataan pendapatan, dan

4. Pemberian upah di atas upah minimum diatur secara internal di perusahaan.

Hal yang paling prinsip dalam kebijakan upah minimum adalah sebagai upaya mewujudkan penghasilan yang layak bagi pekerja atau buruh, dengan mempertimbang-

\footnotetext{
${ }^{8}$ Mit Witjaksono, “Dualisme Pasar Tenaga Kerja dan Dampak Upah Minimum,” JESP 1, no. 1 (2009): 6273.

${ }^{9}$ Prasetio, Dilema BUMN, Benturan Penerapan Business Judgement Rule (BJR) dalam Keputusan Bisnis Direksi BUMN, Cet.1 (Rayyana Komunikasindo, 2014).

${ }^{10}$ Gatot Supramono, Hukum Perseroan Terbatas, Cet.5 (Jakarta: Djambatan, 2009).
} 
kan peningkatan kesejahteraan pekerja atau buruh tanpa mengabaikan peningkatan produktivitas dan kemajuan perusahaan serta perkembangan perekonomian pada umumnya. Kebijakan upah minimum dimaksudkan sebagai upaya perlindungan terhadap pekerja atau buruh yang berpendidikan rendah, tidak mempunyai pengalaman, masa keja di bawah 1 (satu) tahun dan lajang atau belum berkeluarga. Tujuannya untuk mencegah kewenang-wenangan pengusaha selaku pemberi upah dalam memberikan upah kepada pekerja atau buruh. ${ }^{11}$

Ketentuan mengenai upah diatur di dalam Undang-Undang Nomor 13 Tahun 2003 tentang Ketenagakerjaan. Di dalam Pasal 88 ayat (1) menyatakan bahwa setiap pekerja/buruh berhak memperoleh penghasilan yang memenuhi penghidupan yang layak bagi kemanusiaan. Selanjutnya, Pasal 88 ayat (2) menyatakan bahwa untuk mewujudkan penghasilan yang memenuhi penghidupan yang layak bagi kemanusiaan sebagaimana dimaksud dalam ayat (1), pemerintah menetapkan kebijakan pengupahan yang melindungi pekerja/buruh. Kemudian, Pasal 88 ayat 3 memberikan penjelasan bahwa Kebijakan pengupahan yang melindungi pekerja/buruh sebagaimana dimaksud dalam ayat (2) meliputi : ${ }^{\mathbf{2}}$

1. Upah minimum;

2. Upah kerja lembur;

3. Upah tidak masuk kerja karena berhalangan;

4. Upah tidak masuk kerja karena melakukan kegiatan lain di luar pekerjaannya;

5. Upah karena menjalankan hak waktu istirahat kerjanya;

6. Bentuk dan cara pembayaran upah;

7. Denda dan potongan upah;

8. Hal-hal yang dapat diperhitungkan dengan upah;

9. Struktur dan skala pengupahan yang proporsional;

10. Upah untuk pembayaran pesangon; dan

11. Upah untuk perhitungan pajak penghasilan.

\footnotetext{
${ }^{11}$ Eko Wahyudi dan dkk, Hukum Ketenagakerjaan (Jakarta: Sinar Grafika, 2016).

12 "Undang-Undang Nomor 13 Tahun 2003 tentang Ketenagakerjaan."
} 
Bila dianalisa dengan seksama, isi pasal di atas, dapat diasumsikan bahwa undangundang ketenagakerjaan, benar-benar menghendaki adanya perlindungan dan pengupahan yang layak bagi para pekerja/buruh.

\section{Akibat Hukum Bagi Perusahaan Yang Tidak Menerapkan Upah Minimum}

Terdapat beberapa permasalahan yang dihadapi, baik oleh pihak perusahaan maupun pihak pekerja/buruh, agar bisa dan dapat memperoleh apa yang menjadi hak dari masing-masing pihak. Hak-hak yang dimaksud telah ditentukan dalam bentuk yuridis formalnya, dengan isi perjanjian/kontrak yang telah disepakati bersama oleh pihak perusahaan dan pekerja. Sebagaimana penjelasan yang telah di utarakan terdahulu bahwa ada tiga bentuk yuridis formal yang menentukan nilai-nilai hak dan kewajiban antara perusahaan dan para pekerja/buruh yaitu perjanjian kontrak kerja (PKK), peraturan perusahaan (PP), dan kesepakatan kerja bersama (KKB). Masing-masing bentuk perjanjian kerja tersebut mempunyai kandungan isi berbeda-beda yang menyangkut hak-hak dan kewajiban masing-masing perusahaan dan pekerja/buruh. ${ }^{13}$

Berdasarkan Pasal 89 ayat (1) menyatakan bahwa Upah minimum sebagaimana dimaksud dalam Pasal 88 ayat (3) huruf a dapat terdiri atas upah minimum berdasarkan wilayah provinsi atau kabupaten/kota atau upah minimum berdasarkan sektor pada wilayah provinsi atau kabupaten/kota. Kemudian, kewajiban pengusaha membayar upah minimum tercantum di dalam Pasal 90 ayat (1) Undang-Undang 13 Tahun 2003 tentang Ketenagakerjaan yang menyatakan bahwa pengusaha dilarang membayar upah lebih rendah dari upah minimum sebagaimana dimaksud dalam Pasal 89. Ketentuan ini menegaskan bahwa setiap pengusaha wajib memberikan upah minimum kepada pekerja atau buruh. ${ }^{14}$

Ketentuan mengenai upah minimum tentu saja tidak bisa dipenuhi oleh semua perusahaan atau pengusaha mengingat setiap perusahaan atau pengusaha memiliki kondisi dan situasi yang berbeda-beda, misalnya klasifikasi perusahaan yang terdiri dari perusahaan besar, menengah dan kecil yang diukur dari modalnya. ${ }^{15}$ Banyak perusahaan

\footnotetext{
13 Muslimin Muhammad Andi Makasau, "Pengaruh Implementasi Kebijakan Upah Minimum pada Hubungan Kerja Perusahaan dengan Pekerja di Kabupaten Bandung," t.t., 14.

${ }^{14}$ Asikin Zainal dan dkk, Dasar-Dasar Hukum Perburuhan (Jakarta: PT Raja Grafindo Persada, 2006).

${ }^{15}$ Ridwan Khairandy, Pengantar Hukum Dagang, Cet.1 (Yogyakarta: FH UII Press, 2006).
} 
yang kondisi keuangannya yang tidak stabil yang mengakibatkan tidak dapat memenuhi ketentuan upah minimum. Hal tersebut diberikan peluang oleh Undang-Undang Ketenagakerjaan, tepatnya diatur didalam Pasal 90 ayat (2) yang menyatakan bahwa bagi pengusaha yang tidak mampu membayar upah minimum sebagaimana dimaksud dalam Pasal 89 dapat dilakukan penangguhan. Namun, Penangguhan pembayaran upah yang dilakukan oleh pengusaha tidak serta merta menghilangkan kewajiban pengusaha membayar selisih upah minimum selama masa penangguhan.

Mekanisme mengenai penangguhan upah minimum diatur dalam Keputusan Menteri Tenaga Kerja dan Transmigrasi No. KEP-231/MEN/2003 tentang Tata Cara Penangguhan Pelaksanaan Upah Minimum. Pengusaha yang tidak mampu membayar upah minimum sebagaimana yang telah ditetapkan sebelumnya dapat mengajukan permohonan penangguhan upah minimum kepada Gubernur melalui instansi yang bertanggung jawab dalam bidang Ketenagakerjaan Provinsi paling lambat 10 hari sebelum berlakunya upah minimum. Permohonan yang diajukan kepada Gubernur tersebut harus didasarkan pada kesepakatan tertulis antara pihak pengusaha dengan serikat pekerja atau pekerja/buruh. Berdasarkan ketentuan tersebut, dapat dikatakan bahwa untuk dapat mengajukan permohonan, harus didahului dengan adanya persetujuan keduabelah pihak. Jika kesepakat telah tercapai diantara keduabelah pihak, maka langkah selanjutnya adalah menyampaikan permohonan kepada Gubernur. Permohonan penangguhan upah juga harus dilampirkan dengan:

1. Naskah asli kesepakatan tertulis antara pengusaha dengan serikat pekerja atau pekerja perusahaan yang bersangkutan;

2. Laporan keuangan perusahaan yang terdiri dari neraca perhitungan rugi/laba beserta penjelasan-penjelasan untuk 2 (dua) tahun terakhir;

3. Salinan akta pendirian perusahaan;

4. Data upah menurut jabatan pekerja/buruh;

5. Jumlah pekerja/buruh seluruhnya dan jumlah/pekerja yang dimohonkan penangguhan pelaksanaan upah minimum; 
6. Perkembangan produksi dan pemasaran selama 2 (dua) tahun terakhir, serta rencana produksi dan pemasaran untuk 2 (dua) tahun yang akan datang. ${ }^{16}$

Apabila perusahaan yang mengajukan permohonan penangguhan upah berbentuk badan hukum, maka untuk pembuktian laporan perusahaan harus diaudit oleh akuntan publik untuk membuktikan bahwa perusahaan benar-benar tidak mampu membayar upah sesuai ketentuan yang ditetapkan. Selanjutnya, permohonan yang diajukan tersebut akan dianalisis terlebih dahulu oleh Gubernur dengan meminta pertimbangan kepada Dewan Pengupahan Provinsi apakah akan disetujui atau ditolak.

Bentuk penangguhan upah minimum yang diberikan berdasarkan ketentuan Pasal 5 Keputusan Menteri Tenaga Kerja dan Transmigrasi No. KEP-231/MEN/2003 tentang Tata Cara Penangguhan Pelaksanaan Upah Minimum, meliputi:

1. membayar upah minimum sesuai upah minimum yang lama; atau

2. membayar upah minimum lebih tinggi dari upah minimum lama tetapi lebih rendah dari upah minimum baru; atau

3. menaikkan upah minimum secara bertahap. ${ }^{17}$

Selain itu, akibat hukum apabila pengusaha atau perusahaan tidak menerapkan upah minimum kepada pekerja/buruh maka dapat dikenakan sanksi pidana. Sanksi pidana tersebut diatur di dalam Pasal 185 ayat (1) Undang-Undang Nomor 13 Tahun 2003 tentang Ketenagakerjaan yang menyatakan bahwa barang siapa melanggar ketentuan sebagaimana dimaksud dalam Pasal 42 ayat (1) dan ayat (2), Pasal 68, Pasal 69 ayat (2), Pasal 80, Pasal 82, Pasal 90 ayat (1), Pasal 143, dan Pasal 160 ayat (4) dan ayat (7), dikenakan sanksi pidana penjara paling singkat 1 (satu) tahun dan paling lama 4 (empat) tahun dan/atau denda paling sedikit Rp 100.000.000,00 (seratus juta rupiah) dan paling banyak Rp 400.000.000,00 (empat ratus juta rupiah). Kemudian Pasal 185 ayat (2) menegaskan bahwa Tindak pidana sebagaimana dimaksud dalam ayat (1) merupakan tindak pidana kejahatan. Ketetuan-ketentuan tersebut menjelaskan tentang

\footnotetext{
16 “Keputusan Menteri Tenaga Kerja dan Transmigrasi No. KEP-231/MEN/2003 tentang Tata Cara Penangguhan Pelaksanaan Upah Minimum," 2003.

17 "Keputusan Menteri Tenaga Kerja dan Transmigrasi No. KEP-231/MEN/2003 tentang Tata Cara Penangguhan Pelaksanaan Upah Minimum."
} 
kewajiban pengusaha atau perusahaan memiliki kewajiban membayar upah sesuai ketentuan yang telah ditetapkan. ${ }^{18}$

\section{Eksistensi Suatu Perusahaan Terhadap Kenaikan Upah Minimum Di Kabupaten Karawang}

Keberadaan perusahaan memiliki peranan penting dalam suatu negara karena dapat mempengaruhi pertumbuhan ekonomi. Semakin banyak perusahaan akan memberikan dampak positif bagi pembangunan ekonomi yang ada pada suatu wilayah. Adanya perusahaan akan memberikan peluang kerja bagi masyarakat di suatu wilayah sehingga akan meningkatkan kesejahteraan masyarakat. ${ }^{19}$

Dalam ketenagakerjaan, antara pekerja dan pengusaha mempunyai hubungan yang saling menguntungkan. Pekerja memberikan tenaganya untuk produk dan jasa, sedangkan pengusaha membayar upah atas jasa pekerja dalam menciptakan produk, baik berupa barang atau jasa yang dijual pada konsumen. Pemerintah sebagai fasilitator yang menyediakan prasarana mendapatkan keuntungan melalui pajak yang dibayar pengusaha. ${ }^{20}$ Pada prinsipnya, tujuan yang ingin dicapai dalam hubungan industrial adalah ke tangan bekerja bagi para pekerja dan kelangsungan usaha bagi pengusaha, dan untuk itulah diperlukan peran pemerintah sebagai pihak yang tidak terlibat langsung dalam hubungan kerja, dapat bersifat netral dan dapat menjamin pelaksanaan hak dan kewajiban para pihak dalam hubungan kerja. ${ }^{21}$

Problematika yang selalu mendapatkan perhatian dalam hukum ketenagakerjaan adalah masalah upah. Masalah upah selalu bergejolak setiap tahunnya dimana serikat pekerja atau buruh meminta kenaikan upah untuk meningkatkan kesejahteraan pekerja. Beberapa waktu yang lalu, pemerintah Provinsi Jawa Barat resmi menetapkan UMK tahun 2018 di 27 kota/kabupaten. Kabupaten Karawang kembali menjadi daerah yang memiliki UMK paling tinggi sebesar Rp. 3.919.291,13 dan terendah Kabupaten Pangandaran sebesar Rp. 1.558.793,94. Di bawah ini adalah 5 (lima) kota/kabupaten

\footnotetext{
18 "Undang-Undang Nomor 13 Tahun 2003 tentang Ketenagakerjaan."

${ }^{19}$ Zainal Asyhadie, Hukum Bisnis: Prinsip dan Pelaksanaannya di Indonesia (Jakarta: Rajawali Pers, 2016).

20 Fritje Rumimpunu, "Sistem Hubungan Industrial Pancasila di Indonesia dengan Tenaga Kerja, Perusahaan Dilihat dari Aspek UU Tenaga Kerja No.13 Tahun 2003," Jurnal Hukum II, no. 2 (Januari 2014).

${ }^{21}$ Aloysius Uwiyono dan dkk, Asas-Asas Hukum Perburuhan (Jakarta: Rajawali Pers, 2014).
} 
yang memiliki UMK tertinggi untuk tahun 2018 di Jawa Barat dapat kita lihat pada tabel berikut. ${ }^{22}$

Tabel 1.1

\begin{tabular}{|l|l|l|}
\hline No & \multicolumn{1}{|c|}{ Kota/Kabupaten } & \multicolumn{1}{c|}{ UMK } \\
\hline 1 & Kabupaten Karawang & Rp. 3.919.291,19 \\
\hline 2 & Kota Bekasi & Rp. 3.915.353,71 \\
\hline 3 & Kabupaten Bekasi & Rp. 3.837.939,63 \\
\hline 4 & Kota Depok & Rp. 3.584.700,29 \\
\hline 5 & Kota Bogor & Rp. 3.557.146,66 \\
\hline
\end{tabular}

Penetapan UMK tersebut tertuang dalam Keputusan Gubernur Jawa Barat Nomor 561/Kep.1065-Yanbangsos/2017 tentang Upah Minimum Kabupaten/Kota di daerah Provinsi Jawa Barat. Kenaikan UMK tersebut disesuaikan dengan penghitungan yang telah ditetapkan oleh pemerintah yaitu 8,21 persen. Kenaikan tersebut didasarkan pada angka inflasi dan pertumbuhan ekonomi nasional.

Kenaikan upah tersebut tentu saja akan memberikan dampak positif dan negatif bagi pengusaha dan pekerja/buruh. Menurut informasi yang diperoleh di lapangan dari pihak Serikat Pekerja Seluruh Indonesia (SPSI) Kabupaten Karawang, bahwa kenaikan upah tersebut belum sesuai dengan keinginan pekerja/buruh karena kenaikan upah mengacu pada Peraturan Pemerintah No. 78 Tahun 2015 tentang Pengupahan yang dianggap bertentangan dengan Undang-Undang Ketenagakerjaan. Kenaikan upah yang didasarkan pada Peraturan Pemerintah No. 78 Tahun 2015 tentang Pengupahan mengatur kenaikan upah didasarkan pada inflasi dan pertumbuhan ekonomi sehingga kenaikan upah dirasa masih cukup rendah. Kenaikan upah tahun 2018 dikatakan bahwa tidak memberikan dampak apapun terhadap peningkatan kesejahteraan masyarakat. hal tersebut disebabkan karena kenaikan upah juga diikuti dengan kenaikan harga bahan pokok.

\footnotetext{
${ }^{22}$ Solehudin, "UMK Karawang Tertinggi dan Pangandaran Terendah di Jawa Barat."
} 
Kenaikan upah juga sangat dirasakan oleh pengusaha atau perusahaan. Dampak kenaikan upah tahun 2018 ini menyebabkan banyak perusahaan yang melakukan penangguhan upah karena belum sanggup untuk memenuhi ketentuan upah minimum yang telah ditetapkan. Selain itu, dampak kenaikan tersebut juga sampai mengakibatkan perusahaan menjadi tutup atau beralih ke daerah lain yang memiliki standar upah lebih rendah dari Kabupaten Karawang. Perusahaan yang tutup atau bangkrut kebanyakan adalah perusahaan textile karena tidak mampu memenuhi standar upah. Contoh konkrit perusahaan yang tidak mampu membayar upah minimum dan memilih menutup perusahaan adalah PT. Bhina Karya Manunggal yang bergerak di bidang usaha textile, PT. Royal Industries Indonesia yang merupakan perusahaan minyak sayur, dan PT. Bukyung yang memiliki bidang usaha pembuatan sepatu.

Dari sisi perusahaan, kenaikan upah akan sangat memberikan pengaruh terhadap kondisi perusahaan. Kenaikan upah akan mengakibatkan biaya operasional pun naik termasuk gaji perusahaan, sedangkan kondisi perusahaan banyak yang sedang mengalami kondisi yang tidak stabil dalam beberapa tahun terakhir dikarenakan kebijakan pemerintah yang tidak konsisten.

Kenaikan upah ternyata tidak berpengaruh untuk semua perusahaan, bahkan banyak juga perusahaan yang mampu mengikuti dan memenuhi kenaikan upah minimum. Sebagai contohnya adalah PT. Ajinomoto Indonesia. Kebijakan upah minimum yang diterapkan di PT. Ajinomoto hanya dijadikan ukuran upah minimal atau terendah dan kenaikan upah dilakukan setiap bulan April. Ketentuan upah minimum dikatakan tidak menjadi masalah yang berat bagi perusahaan karena ketentuan itu merupakan kebijakan pemerintah yang harus dipatuhi.

Berdasarkan uraian tersebut di atas, kenaikan upah memiliki dampak yang berbeda-beda baik bagi pekerja/buruh maupun pengusaha atau perusahaan. Bagi pekerja/buruh kenaikan tersebut tidak memberikan dampak apapun, khususnya berkaitan dengan peningkatan kesejahteraan bagi pekerja karena kenaikan dirasa cukup rendah dan tidak sesuai dengan harga kebutuhan pokok yang juga mengalami kenaikan. Sedangkan bagi perusahaan, kenaikan upah minimum cukup berpengaruh terhadap eksistensi suatu perusahaan karena banyak perusahaan yang tidak mampu memenuhi ketentuan tersebut dan memilih menutup perusahaan atau beralih ke daerah lain yang 
memiliki standar upah lebih rendah. Namun, bagi perusahaan asing atau perusahaan besar kenaikan upah minimum tidak terlalu berpengaruh karena upah minimum hanya dijadikan upah terendah sehingga eksistensi perusahaan tidak berdampak apapun.

\section{Kesimpulan}

Berdasarkan ketentuan di dalam Undang-Undang Nomor 13 Tahun 2013 tentang Ketenagakerjaan bahwa setiap pengusaha wajib membayar upah sesuai ketentuan atau upah minimum. Bagi perusahaan yang tidak mampu membayar upah minimum maka disediakan mekanisme untuk melakukan penangguhan upah sampai perusahaan mampu untuk membayar upah minimum tanpa menghilangkan kewajiban pengusaha membayar selisih upah yang ditangguhkan. Selain itu, pengusaha yang tidak membayar upah sesuai ketentuan maka dapat dikenakan sanksi pidana sebagaimana yang tercantum di dalam Pasal 185 Undang Undang-Undang Nomor 13 Tahun 2013 tentang Ketenagakerjaan yang dikategorikan sebagai suatu kejahatan.

kenaikan upah memiliki dampak yang berbeda-beda baik bagi pekerja/buruh maupun pengusaha atau perusahaan. Bagi pekerja/buruh kenaikan tersebut tidak memberikan dampak apapun, khususnya berkaitan dengan peningkatan kesejahteraan bagi pekerja karena kenaikan dirasa cukup rendah dan tidak sesuai dengan harga kebutuhan pokok yang juga mengalami kenaikan. Kemudian, bagi perusahaan kenaikan upah minimum cukup berpengaruh terhadap eksistensi suatu perusahaan karena banyak perusahaan yang tidak mampu memenuhi ketentuan tersebut dan memilih menutup perusahaan atau beralih ke daerah lain yang memiliki standar upah lebih rendah. Namun, bagi perusahaan asing atau perusahaan besar kenaikan upah minimum tidak terlalu berpengaruh karena upah minimum hanya dijadikan upah terendah sehingga eksistensi perusahaan tidak berdampak apapun.

\section{Daftar Pustaka}

Aloysius Uwiyono, dan dkk. Asas-Asas Hukum Perburuhan. Jakarta: Rajawali Pers, 2014.

Asikin Zainal, dan dkk. Dasar-Dasar Hukum Perburuhan. Jakarta: PT Raja Grafindo Persada, 2006. 
Asri Wijayanti. Hukum Ketenagakerjaan Pasca Reformasi. Jakarta: Sinar Grafika, 2009.

Eko Wahyudi, dan dkk. Hukum Ketenagakerjaan. Jakarta: Sinar Grafika, 2016.

Fajarwati, Diana. "Evaluasi Pelaksanaan Kebijakan Perumusan Upah Minimum Kota Bekasi Tahun 2010," t.t., 14.

Fritje Rumimpunu. "Sistem Hubungan Industrial Pancasila di Indonesia dengan Tenaga Kerja, Perusahaan Dilihat dari Aspek UU Tenaga Kerja No.13 Tahun 2003." Jurnal Hukum II, no. 2 (Januari 2014).

Gabriella Ayu Fajar T.W., Hermawan, dan Ainul Hayat. "Persepsi Pekerja Terhadap Implementasi Kebijakan Upah Minimum Kota (Umk) (Studi Di Kecamatan Sukun Kota Malang)." Jurnal Administrasi Publik (JAP) 1, no. 3 (t.t.): 125-34.

Gatot Supramono. Hukum Perseroan Terbatas. Cet.5. Jakarta: Djambatan, 2009.

"Keputusan Menteri Tenaga Kerja dan Transmigrasi No. KEP-231/MEN/2003 tentang Tata Cara Penangguhan Pelaksanaan Upah Minimum,” 2003.

Makasau, Muslimin Muhammad Andi. "Pengaruh Implementasi Kebijakan Upah Minimum pada Hubungan Kerja Perusahaan dengan Pekerja di Kabupaten Bandung," t.t., 14.

Mit Witjaksono. "Dualisme Pasar Tenaga Kerja dan Dampak Upah Minimum.” JESP 1, no. 1 (2009): 62-73.

Muhammad Iqbal Damanik. "Upah Minimum Dalam Politik Media Massa (Studi Analisis Wacana Kritis Keberpihakan Harian Koran Tempo dan Harian Kompas dalam Pemberitaan Polemik Penentuan Upah Minimum Kawasan Industri Bekasi - Jawa Barat).” Jurnal Ilmu Komunikasi Flow 1, no. 3 (2013): 1-15.

Nanda, Firman Widia. "Peran Pemerintah Daerah Dalam Pelaksanaan Upah Minimum Regional Bagi Usaha Kecil Dan Menengah (Studi Di Dinas Sosial Dan Tenaga Kerja Kota Kediri)," t.t., 17.

Prasetio. Dilema BUMN, Benturan Penerapan Business Judgement Rule (BJR) dalam Keputusan Bisnis Direksi BUMN. Cet.1. Rayyana Komunikasindo, 2014.

Ridwan Khairandy. Pengantar Hukum Dagang. Cet.1. Yogyakarta: FH UII Press, 2006.

Solehudin, Mukhlis Dinillah, Mochamad. "UMK Karawang Tertinggi dan Pangandaran Terendah di Jawa Barat." detiknews. Diakses 11 Juni 2019. https://news.detik.com/berita-jawa-barat/d-3737173/umk-karawang-tertinggidan-pangandaran-terendah-di-jawa-barat.

"Undang-Undang Nomor 13 Tahun 2003 tentang Ketenagakerjaan,” 2003.

Zainal Asyhadie. Hukum Bisnis: Prinsip dan Pelaksanaannya di Indonesia. Jakarta: Rajawali Pers, 2016. 